\title{
The importance of customer satisfaction and delight on loyalty in the tourism and hospitality industry
}

\author{
Mi-Ran Kim ${ }^{1}$
}

Received: 23/07/2011

${ }^{1}$ Michigan State University, phone: 1-517-303-9936, e-mail: kimmi8@msu.edu

Supervisor: Professor Christine A. Vogt, PhD; Professor Bonnie J. Knutson, PhD

Institution awarding the Ph. D. Degree: Michigan State University, USA.

Date of defence: $18^{\text {th }}$ August 2010

(C) 2011 International University College. All rights reserved

Citation: Kim, M. R. (2011), The importance of customer satisfaction and delight on loyalty in the tourism and hospitality industry. Doctoral dissertation summary. European Journal of Tourism Research 4(2), pp. 226-228

\section{Goal and objectives of the dissertation Goal}

This study is to contribute to the development of the body of knowledge of customer satisfaction, delight, and loyalty studies in the context of the tourism and hospitality industry. Additionally, this study is expected to provide a deeper understanding of customer satisfaction, delight, and loyalty for managers to more effectively serve customers by better understanding loyalty creation and retention.

\section{Objectives}

-To examine relationships among customer satisfaction, delight, and loyalty in the context of the tourism and hospitality industry.

-To understand the existence of cognitive, affective, conative, and action loyalties.

-To test the differences in the relationships among customer satisfaction, delight, and loyalty between first-time and repeat guests

-To test the differences in the relationships among customer satisfaction, delight, and loyalty between loyalty program members and non-members.

\section{Methodology}

To test relationships among factors, a survey was conducted on the overnight hotel guests who stayed at a Midwestern resort during the summer of 2009 in the months of July, August, and September. The total sample size was 3709 (online surveys: 3459 and paper surveys: $250)$ and the subjects of this study were 1660 guests who completed either an online (1573 subjects, $46 \%$ of response rate) or paper survey (87 subjects, $35 \%$ of response rate). The survey instrument consists of six sections including the respondents' demographic data and travelling characteristics. To answer the research questions, structural equation modelling (SEM) was conducted to explore the relationships among customer satisfaction, delight, and loyalty. The Statistical Package for the Social Science (SPSS) was also used for all descriptive analyses including the frequency distributions.

\section{Results}

The findings support seven of the eight hypotheses. Customer satisfaction had significant direct influences on cognitive and 
affective loyalty. The influence of customer satisfaction on cognitive loyalty $(\beta=0.69$, $p<0.001$ ) was larger than that on affective loyalty $(\beta=0.35, \quad p<0.001)$. Customer delight had a significant influence on cognitive and affective loyalty. The influence of customer delight on affective loyalty $(\beta=0.51, p<0.001)$ was larger than that on cognitive loyalty $(\beta=0.28, p<0.001)$. The influence of customer delight on cognitive loyalty $(\beta=0.28, p<0.001)$ was smaller than that of customer satisfaction on cognitive loyalty $(\beta=0.69, p<0.001)$ (did not support the hypothesis). However, the influence of customer delight on affective loyalty $(\beta=0.51, p<0.001)$ was larger than that of customer satisfaction on affective loyalty $(\beta=0.35, \quad p<0.001)$. Cognitive and affective loyalty had significant influences on conative loyalty. The influence of affective loyalty on conative loyalty $(\beta=0.59, p<0.001)$ was larger than that of cognitive loyalty on conative loyalty $(\beta=0.31, p<0.05)$. Lastly, conative loyalty had significant influences on action loyalty $(\beta=0.80$, $p<0.001)$. Sixty four percent of variance in action loyalty was explained by the influences of conative loyalty. Seventy-six percent of variance in conative loyalty was explained by the influences of cognitive and affective loyalty. Customer satisfaction and delight explained 82 percent of variance in cognitive loyalty and 63 percent in affective loyalty.

From the additional analysis between the groups of first-time guests and repeat guest, customer delight has a greater effect on cognitive loyalty and affective loyalty in the group of first-time guests $(\beta=0.35, \beta=0.53)$ compared to the group of repeat guests $(\beta=0.24, \beta=0.41)$. Customer satisfaction has a greater effect on cognitive loyalty and affective loyalty in the group of repeat guests $(\beta=0.68$, $\beta=0.45$ ) compared to the group of first-time guests $(\beta=0.63, \beta=0.36)$. For cognitive loyalty, there is no direct effect on conative loyalty in the group of first-time guests while cognitive loyalty has a positive effect on conative loyalty in the group of repeat guests $(\beta=0.85)$.

Additional analysis between the groups of loyalty program members and non-members showed that customer delight has a greater effect on cognitive loyalty and affective loyalty in the group of loyalty program non-members
( $\beta=0.33, \beta=0.54)$ compared to the group of loyalty program members $(\beta=0.30, \beta=0.46)$. Customer satisfaction has a greater effect on affective loyalty in the group of loyalty program members $(\beta=0.40)$ compared to the group of loyalty program non-members $(\beta=0.36)$. Cognitive loyalty has a greater effect on conative loyalty in the group of loyalty program non-members $(\beta=0.64)$ compared to the group of loyalty program members $(\beta=0.31)$. Affective loyalty has a greater effect on conative loyalty in the groups of loyalty program members $(\beta=0.56)$ compared to the group of loyalty program non-members $(\beta=0.35)$.

\section{Theoretical conclusions}

This study is one of few empirical studies on customer satisfaction, delight, and loyalty and provides a foundation for researchers in the understanding of the relationships among customer satisfaction, delight, and loyalty in the context of tourism and hospitality industry. In particular, this study extends support for the conceptualization of customer satisfaction and delight as distinct constructs and also shows that both customer satisfaction and delight are important antecedents of loyalty; specifically, customer satisfaction and delight have direct significant relationships with cognitive and affective loyalty. Another theoretical implication of this study is its contribution to better understand four phases of loyalty development: cognitive, affective, conative, and action loyalties.

\section{Practical application of the dissertation}

Managers have mostly focused on improving customer satisfaction to increase customer loyalty. This study shows that managers need to understand the importance of not only customer satisfaction but also delight in directly driving customer loyalty. Now, achieving mere customer satisfaction is not enough to get customers' attention and gain loyalty among other competitors; the changes in the tourism and hospitality industry demand more than customer satisfaction-style management. Therefore, being knowledgeable about customer delight can be a valuable motivator for managers in developing marketing strategy and they need to understand that the key to successfully applying delight-generating strategies lies in the selective usage of the 
concept and in creating differentiated and personalized services so that the competitors are not able to easily copy the delight program. As a good example of accomplishing delightgenerating strategies, the front-line personnel, those who are mostly in contact with customers, can be a critical source to deliver delight effectively through good relationships with customers.

\section{Content of the dissertation}

\section{Abstract of chapter one}

The first chapter introduces constructs of customer satisfaction, delight, and loyalty and presents problem statement; purpose of study; proposed research model and hypotheses; delimitations; and definitions of terms. The problem of this research was to examine the impact of customer satisfaction and delight on loyalty with a more comprehensive model than previous research efforts as well as with valid and reliable empirical testing.

\section{Abstract of chapter two}

The literature related to this study is introduced in this chapter. The literature is presented under the following topics: (1) Consumer Behaviour; (2) Customer Satisfaction; (3) Customer Delight; (4) Customer Loyalty; and (5) Affect and Cognition. This chapter discusses that customer satisfaction has been a focus of researchers and marketers as an important antecedent of customer loyalty. Recent studies propose customer delight as a new variable of interest in satisfaction research and it is defined as a combination of high pleasure (joy, elation) and high activation (surprise). Like customer satisfaction, customer loyalty is also considered crucial to the success of a business organization and in recent years, interest has also grown in understanding the multi-phases of loyalty such as cognitive, affective, conative, and action loyalty as a useful way to segment customers with differential strategies.

\section{Abstract of chapter three}

This chapter discusses the research methodology that was used to answer the proposed research hypotheses. This chapter includes: (1) research design including rational for research method, sampling, pilot study, and data collection procedures; (2) survey measurement; and (3) data analysis. Data were collected from guests who stayed at a Midwestern resort during a peak summer vacation time using an online and a paper survey. The model was tested applying structural equation modelling (SEM) to estimate the relationship between customer satisfaction, delight, and loyalty in a tourism and hospitality context.

\section{Abstract of chapter four}

This chapter presents the results on the customer satisfaction, delight, and loyalty model testing including eight hypotheses tests. The findings support the proposed model and suggest that (1) customer satisfaction has a direct and positive influence on cognitive and affective loyalty; (2) customer delight has a direct and positive influence on cognitive and affective loyalty; (3) customer satisfaction has a greater influence on cognitive loyalty than on customer delight; (4) customer delight has a greater influence on affective loyalty than on customer satisfaction; (5) cognitive and affective loyalties have a direct and positive influence on conative loyalty; and (6) conative loyalty has a direct and positive influence on action loyalty. Additional results between different groups (first-time guests vs. repeat guests; loyalty program members vs. nonmembers) on the customer satisfaction, delight, and loyalty model testing are presented.

\section{Abstract of chapter five}

This chapter discusses the implications of the study, as well as opportunities for future research and limitations of this study. The results are presented with current literature perspectives and the theoretical contributions of the study are discussed including managerial implications. This study will contribute to the body of knowledge on customer satisfaction, delight, and loyalty and provide important theoretical and applied suggestions for the tourism and hospitality industry. Future studies should replicate the findings and test the model with different samples such as types of accommodations (e.g., business hotel, bed and breakfast), places (e.g., other states, other countries), and service industries (e.g., restaurant, airline, cruise). 